\title{
Endoparasites of the eastern rock sengi (Elephantulus myurus) from South Africa
}

\author{
${ }^{1}$ Heike Lutermann, ${ }^{1}$ Katarina Medger, and Kerstin Junker*
}

${ }^{1}$ Mammal Research Institute, Department of Zoology and Entomology, University of Pretoria, Private Bag X20, Hatfield 0028, South Africa. *ARC-Onderstepoort Veterinary Institute, Private Bag X05, Onderstepoort, 0110, South Africa. Correspondence should be sent to: hlutermann@zoology.up.ac.za

BSTRACT: The endoparasite fauna of the eastern rock sengi (Elephantulus myurus Thomas and Schwann) was studied for the first time for any sengi species from September 2007 until August 2008 in the Limpopo Province of South Africa. From the 121 sengis examined, we recovered 11 endoparasite taxa including 9 nematodes, 1 cestode family (Hymenolepididae) and 1 pentastomid species [Armillifer armillatus (Wyman, 1834)]. The overall endoparasites prevalence was high at 100\% and largely attributable to the nematode Maupasina weissi Seurat, 1913, with only a single individual being parasite free. Despite the high diversity, species richness was low $(1.58 \pm 0.06)$ and only $M$. weissi and spiruroid larvae occurred at a prevalence exceeding $8 \%$. The abundance of $M$. weissi varied significantly between seasons and was lowest in summer and autumn. In contrast, the abundance of spiruroid larvae remained relatively constant across seasons in males but was significantly higher in spring and summer compared to winter in females. These patterns may be generated by an accumulation of $M$. weissi with age as well as sex-specific seasonal shifts in diet. An updated list on the hosts and geographic range of parasites of sengis is provided.

Sengis (Macroscelidea) are small insectivorous mammals endemic to Africa comprising 4 genera (Rhynchocyon Peters, Macroscelides A. Smith, Petrodromus Peters and Elephantulus Thomas and Schwann) and 19 extant species of which 11 are from the genus Elephantulus (Rathbun, 2009; Dumbacher et al., 2014). They have a wide distribution across Africa which includes the entire continent apart from western Africa and the Sahara desert. Members of Rhynchocyon and the monotypic genus Petrodromus inhabit mesic woodlands and tropical rainforests while the other 2 genera exploit more arid savannah and desert habitats (Rathbun, 2009). Despite their wide geographic distribution sengis have received comparatively limited attention when it comes to their endoparasite fauna and the available records are restricted to incidental observations of a taxonomic nature mainly from Elephantulus rozeti (Duvernoy) in Tunisia (Seurat, 1913, 1914; Quentin, 1978; Quentin and Seureau, 1978) and Petrodromus tetradactylus Peters from central and east Africa (Bayliss, 1934; van den Berghe and Vuylsteke, 1938). In contrast, the center of biodiversity of sengis lies in southern Africa with 3 genera and 7 species occurring in South Africa, and E. rozeti being the only species found north of the Sahara (Rathbun,
2009). Conversely, only a single nematode record is available from South Africa for Macroscelides proboscideus Shaw (Ortlepp, 1937). However, either the indicated geographic location (former Western Transvaal, corresponding to the northeastern part of today's Northwest Province) or the host species was misidentified, since this locality lies outside the distributional range of $M$. proboscideus (Dumbacher et al., 2014). The vast majority of endoparasites reported for sengis parasitize the gastrointestinal tract (GIT) with the exception of Thelazia lewisi Ogden, 1968 retrieved from the eyelid of Rhynchocyon cirnei Peters in Uganda and the pentastomid Armillifer armillatus Wyman, 1845 from an unspecified sengi species (Zumpt, 1961; Ogden, 1968). In the current study we examined the GITs of eastern rock sengis (Elephantulus myurus Thomas and Schwann) for endoparasites and evaluated the contributions of season and host sex to their species richness, prevalence and abundance. Elephantulus myurus has a wide geographic distribution, including parts of Zambia, Mozambique, Zimbabwe, Botswana and South Africa (Skinner and Chimimba, 2005). The current study constitutes the first long-term assessment of the endoparasite fauna in the order Macroscelidea. 


\section{MATERIALS AND METHODS}

Sengis were captured between September 2007 and August 2008 in a private game reserve $\left(22^{\circ} 58^{\prime} \mathrm{S}, 2^{\circ} 25^{\prime} \mathrm{E}\right)$ in the Limpopo Province of South Africa using Sherman live traps baited with a mixture of oats, peanut butter and sardines (permit number: CPM-333-00002) as part of a study on their reproductive biology (Medger et al., 2012). Additional captures were made during October 2008 and April 2009. A maximum of 5 individuals of each sex were caught on a monthly basis. All animals included in the current study ( $\mathrm{n}=121,58$ males, 63 females) had a body mass exceeding $36 \mathrm{~g}$ suggesting that they were sub-adults or adults (Medger et al., 2012). Once captured, animals were maintained in standard rodent cages with wood shavings as bedding and fed a diet of commercial dog food (Promeal Ltd, Atlantis, South Africa), Pro Nutro (high protein cereal; Pioneer Foods Ltd, Epping, South Africa), mealworms and grated carrots and apple with water available ad libitum. They were killed with an overdose of halothane within a maximum of 8 days after capture. The body cavity was opened, the GIT removed in its entirety and stored in 70\% ethanol. Endoparasites encountered in the body cavity during this procedure were removed and also stored in $70 \%$ ethanol but no systematic search for endoparasites in the body cavity was conducted. The GIT was later separated into stomach, small intestine, cecum and colon. Each of these sections was examined separately by flushing out the contents and any parasites encountered were stored in $70 \%$ ethanol. All helminths were cleared in lactophenol while pentastomids were cleared in Hoyer's medium before being examined under a compound light microscope for identification. Voucher specimens were deposited in the National Collection of Animal Helminths, Agricultural Research Council-Onderstepoort Veterinary Institute, Onderstepoort, South Africa (accession numbers $\mathrm{S} / 2015 / 5-14)$.

We recorded the presence/absence as well as the number of individuals for each parasite taxon encountered and calculated the species richness, prevalence and mean abundance following Bush et al., (1997). Since the number of individuals of each sex per month was low, we pooled data across seasons (spring: September-November, summer: DecemberFebruary, autumn: March-May and winter: JuneAugust) for analyses. To assess possible effects of season and host sex on the species richness, prevalence and abundance, we employed generalized linear models (GLMs) with a Poisson, a binomial (prevalence) and negative binomial (abundance) data distribution and a loglink function, respectively. Season and sex as well as the interaction between sex and season were included as independent variables in the model. Host body mass was added as covariate. Only 2 parasite taxa occurred at sufficiently high prevalence to allow a meaningful statistical analysis and hence these analyses were only carried out for these parasites. However, since one of these was encountered in all but 1 individual, only the abundance was considered for this parasite species. For significant terms least significant differences (LSD) post-hoc tests were carried out. All analyses were conducted using SPSS v.21 and results are reported as means $\pm \mathrm{SE}$.

\section{RESULTS}

Eleven endoparasite taxa were recovered from the 121 host specimens dissected. Parasites were determined as: 1 unidentified cestode from the family Hymenolepididae, A. armillatus (Pentastomida, Porocephalidae), and the nematodes Syphacia minuta Greenberg, 1969 (Oxyuridae), Moaciria sp. and Spinicauda sp. (Heterakidae), Maupasina weissi Seurat, 1913 (Subuluroidea, Maupasinidiae), Abbreviata spp. and Physaloptera spp. (Physalopteridae), Trichuris spp. (Trichuridae), adult specimens belonging to Physalopterinae which could not be further identified, as well as unidentified larvae of Spiruroidea (Table I). Despite this fairly large species diversity the species richness was low $(1.58 \pm 0.06, \mathrm{CI}: 1.47-1.69)$ and ranged from 1-3. It was neither significantly affected by season $\left(\chi^{2}\right.$ $=1.841, \mathrm{df}=3, \mathrm{p}=0.606), \operatorname{sex}\left(\chi^{2}=0.001, \mathrm{df}=\right.$ $1, p=0.974)$, the interaction between season and sex $\left(\chi^{2}=0.605\right.$, df $\left.=3, p=0.895\right)$ nor the body mass of the host $\left(\chi^{2}=0.006, \mathrm{df}=1, \mathrm{p}=0.941\right)$. Although most endoparasite taxa retrieved occurred only at low prevalence, the overall endoparasite prevalence was high $(100 \%)$. This was largely attributable to the high prevalence of 
M. weissi (Table I) with only 1 individual not being infected. The abundance of $M$. weissi differed significantly between seasons $\left(\chi^{2}=\right.$ 13.533, df $=3, p=0.004$, Fig. 1A). It was significantly lower in summer compared to spring and winter ( $p \leq 0.044$, Fig. 1A). In addition, it was significantly greater in winter compared to autumn (LSD: $\mathrm{p}=0.026$ ), while none of the remaining pairwise comparisons was significant $(\mathrm{p} \geq 0.190)$. Neither $\operatorname{sex}\left(\chi^{2}=2.799\right.$, $\mathrm{df}=1, \mathrm{p}=0.094)$ nor the interaction between season and sex was significant $\left(\chi^{2}=0.694, \mathrm{df}=\right.$ $3, \mathrm{p}=0.875)$. However, the abundance of $M$. weissi increased significantly with body mass (estimate \pm SE: $0.051 \pm 0.021, \chi^{2}=6.192, \mathrm{df}=1$, $\mathrm{p}=0.013$ ).

Unidentified spiruroid larvae were the only other endoparasites exceeding a prevalence of $8 \%$ (Table I). However, the prevalence of spiruroid larvae was not significantly affected by either season $\left(\chi^{2}=4.865, \mathrm{df}=3, \mathrm{p}=0.182\right)$, sex $\left(\chi^{2}=1.648, \mathrm{df}=1, \mathrm{p}=0.199\right)$ or body mass $\left(\chi^{2}\right.$ $=0.124$, df $=1, p=0.725)$. Similarly, the interaction between season and sex was not significant $\left(\chi^{2}=1.119\right.$, df $\left.=3, p=0.772\right)$. In contrast, the abundance of spiruroid larvae differed significantly between seasons $\left(\chi^{2}\right.$ $=14.169$, $\mathrm{df}=3, \mathrm{p}=0.003$ ). It was significantly higher in summer $(1.19 \pm 0.22, \mathrm{CI}: 0.84-1.71)$ compared to autumn $(0.48 \pm 0.12, \mathrm{CI}: 0.30-0.78)$ and winter $(0.37 \pm 0.14, \mathrm{CI}: 0.17-0.76, \mathrm{p} \leq 0.004)$. In addition, it was significantly greater in spring $(1.00 \pm 0.22$, CI: $0.64-1.55)$ compared to autumn and winter $(\mathrm{p} \leq 0.041)$. None of the remaining pairwise comparisons was significant $(p \geq$ 0.528 ). The abundance of spiruroid larvae was significantly lower in females $(0.52 \pm 0.12, \mathrm{CI}$ : $0.34-0.80)$ compared to males $(0.89 \pm 0.13, \mathrm{CI}$ : $0.67-1.19, \chi^{2}=4.028$, df $\left.=1, p=0.045\right)$. However, it was not significantly affected by body mass $\left(\chi^{2}=0.255\right.$, df $\left.=1, p=0.614\right)$. Furthermore, the interaction between season and sex was significant $\left(\chi^{2}=18.617\right.$, df $=3, p<$ 0.0001 , Fig. 1B). Among female sengis the abundance of spiruroid larvae was significantly greater in summer than in all other seasons $(\mathrm{p} \leq$ 0.015 , Fig. 1B). Furthermore, it was significantly greater in spring compared to autumn and winter for females $(\mathrm{p} \leq 0.042)$. In addition, spiruroid larvae abundance was significantly higher for males compared to females in winter (LSD: $p=$
0.002) while the opposite was true in summer (LSD: $p=0.003$, Fig. 1B). None of the remaining pairwise comparisons was significant $(p \geq 0.281)$.

\section{DISCUSSION}

Prior to the present study, 15 species of helminths had been reported as parasite of the Macroscelidea, belonging to nematodes (11), cestodes (3), and pentastomids (1) (Seurat, 1915; Baer, 1926, 1933; Gedoelst, 1916; Sandground, 1933, Baylis, 1934; Zumpt, 1961; Ogden, 1968; Bain and Quentin, 1977, Quentin, 1978; Quentin and Seureau, 1978; Hugot and Cuisance, 1990) (Table II). The species richness of endoparasites retrieved from the current study nearly equals the species richness previously known for the entire order. In addition, Baylis (1934) mentioned specimens resembling members of the genus Nycteridostrongylus Baylis, 1930 and small oxyurids recovered from $P$. tetradactylus (syn. $P$. nigriseta Neumann) in Tanzania. No systematic assessment of the endoparasite fauna of any other sengi species is currently available for comparison but the species richness recorded in the present study is substantially larger than that reported for sympatric African spiny mice (Acomys spinosissimus Peters) (Lutermann et al., 2014). Although this may be due to the smaller body size of $A$. spinosissimus (ca. $20 \mathrm{~g}$ ), it is also likely to be a result of the differences in diet between the 2 species. The insectivorous diet of sengis in contrast to the omnivorous diet of $A$. spinosissimus is likely to have contributed to the large number of endoparasite taxa that use arthropods as intermediate hosts found in the GIT of E. myurus (Skinner and Chimimba, 2005). At the same time, the current study is the first to report the presence of the directly transmitted oxyurid nematode $S$. minuta in a species other than a member of the genus Acomys I. Geoffroy (Lutermann et al., 2014). It is noteworthy that species of Syphacia Seurat, 1916 are typically considered parasites of rodents (Petter and Quentin, 1976), whereas members of the spinicaudine genera Spinicauda Travassos, 1920 and Moaciria Freitas, 1956 are typically parasites of reptiles (Chabaud, 1978). Syphacia minuta was recovered from 2 host individuals only, and Spinicauda sp. and Moaciria sp. were registered in only 1 of the 
sengis; thus, their presence should currently be considered an accidental infection rather than an expansion of their host range.

Species of the pentastomid genus Armillifer Sambon, 1922 are parasites of the respiratory tract of snakes, especially pythons, and larval stages have been reported from a vast range of mammalian intermediate hosts such as antelopes, suids, primates, including humans, small and large carnivores, as well as small mammals, such as Potamogale sp., Steatomys sp., Cricetomys spp. and A. spinosissimus (Fain, 1961; Greve and Russell,1974; Ogunsusi and Mohammed, 1978; Riley and Self, 1981; Lutermann et al., 2014). The presence of Armillifer larvae in A. spinosissimus and $E$. myurus in Limpopo Province constitute the first records of this genus from small mammals in South Africa and the first indication of the presence of this genus in South African snakes. Earlier reports recorded the presence of Raillietiella Sambon, in Vaney and Sambon, 1910 (Raillietiellidae) in Bitis spp. and Psammophis spp. (Hering-Hagenbeck, 2001; Lutermann et al., 2014) only.

The endoparasite assemblage of $E$. myurus was dominated by $M$. weissi, a nematode species also found in E. rozeti in Tunisia, $R$. cirnei in the DRC as well as an incorrectly identified Elephantulus sp. in South Africa (Table II). That the same parasite species is found across such divergent host subfamilies as Macrosclelidinae (Elephantulus) and Rhynchoconinae (Rhynchocyon) that differ substantially in size and habitat preferences but share life-history traits (Rathbun, 2009) as well as the large geographical distribution, is suggestive of a long co-evolutionary history of this parasite and the Macroscelidea.

Spiruroid larvae were the only other endoparasites found in substantial numbers in $E$. myurus. Their resemblance to descriptions of larval stages of Streptopharagus Blanc, 1912 (Chabaud, 1954) and Mastophorus Diesing, 1853 (Quentin, 1969; 1970) suggests the presence of several genera, but in the absence of adults of these genera identifications could not be confirmed. In combination with the other spiruroids, such as Physolaptera sp. and Abbreviata sp., it suggests that E. myurus is host to a diversity of Spiruroida. This corresponds with the diversity of spirurids across the order Macroscelidea (Bayliss, 1934; Quentin, 1978; Quentin and Seureau, 1978) and suggests that the spiruroid larvae found in the current study may represent several species.

The abundance of both of the most prevalent nematode taxa varied seasonally; however, their patterns were vastly different with a nadir in summer and peaks in spring and winter for $M$. weissi while the abundance of spiruroid larvae was lowest in winter and highest in spring and summer. Two mechanisms may explain this difference. Firstly, if $M$. weissi accumulates over time, the recruitment of subadults in the sengi population as the breeding season progresses (Medger et al., 2012) may account for the lower abundance of this species in summer and autumn. This hypothesis is further supported by the positive correlation between sengi body mass and $M$. weissi abundance. However, since sengis achieve adult weight within a few weeks after birth (K. Medger, unpubl. data), we could not unequivocally identify juveniles based on their body mass and can thus not further evaluate this hypothesis. Although juvenile recruitment may have contributed to the pattern observed for $M$. weissi, it cannot explain the variation in the abundance of spiruroid larvae. Nevertheless, if both of these nematode taxa use different intermediate hosts, seasonal shifts in the arthropods consumed may explain the seasonal patterns. Although under laboratory conditions $M$. weissi has been successfully propagated in Locusta migratoria (L.) (Acrididae) and Ornithodoros erraticus Lucas (Argasidae) (Bain and Quentin, 1977; Quentin and Verdier, 1979), the myrmecophagous habit of sengis suggests that ants and/or termites are likely to be the intermediate host for this nematode in the study area (Rathbun, 2009). These are presumably the staple in the diet of E. myurus throughout the year, but during spring and summer the available insects may increase in abundance and diversity. If this is reflected in the diet of E. myurus, it could account for the observed variation in nematode abundance. At the same time, the dominance of ants and termites in the diet of the study species could account for the low endoparasite species richness observed in the current study. 
While the abundance of spiruroid larvae was relatively constant among males it varied dramatically among females. If the hypothesis proposed above proves to be correct this would suggest that males include a relatively fixed proportion of non-myrmecophagous prey in their diet while females greatly increase their intake of such insects during spring and summer but only consume low numbers during winter. Given that ants and termites are small and of low nutritional value (Redford and Dorea, 1984), the high energetic demands of pregnancy and lactation (Speakman, 2008) compared to the low reproductive investment of the monogamous males, that does not extend beyond mating (Rathbun, 2009), makes such sex-specific strategies likely.

In summary, the endoparasite species diversity found for E. myurus was fairly high but dominated by 2 nematode taxa, $M$. weissi and spiruroid larvae. The former has previously been reported for other sengi species over a wide geographical range suggesting host specificity for the order Macroscelidea. We suggest that fluctuations in the abundance of 2 common parasites are linked to juvenile recruitment and/or seasonal and sex-specific differences in diet.

\section{ACKNOWLEDGMENTS}

This study was funded by the NRF and the University of Pretoria. We furthermore acknowledge the support of Prof. N. C. Bennett through his DST/NRF chair. We are indebted to the staff of the Goro Game Reserve, particularly D. Dewsnap, for permission to collect animals in the reserve and their continuous support. In addition, we thank the Department of Environmental Affairs, Limpopo Province for issuing capture permits and numerous volunteers for help in the field. The study was approved by the Animal Ethics Committee of the University of Pretoria (EC028-07).

\section{LITERATURE CITED}

Baer, J. G. 1926. Contributions to the helminthfauna of South Africa. Mammalian cestodes. Union of South Africa, Department of Agriculture. 11th and 12th Reports of the Director of Veterinary Education, Part 1: 61-136.
1933. Contribution à l'étude de la faune helminthologique africaine. Revue Suisse de Zoologie 40: 31-84.

Bain, O., and J.-C. Quentin. 1977. Développement de Dipetalonoma (A.) weissi, Filaire de Macroscélide, chez un Ornithodore. Annales de Parasitolgie Humaine et Comparée 5: 569-575.

Bayliss, H. A. 1934. On the collection of cestodes and nematodes from small mammals in Tanganyika Territory. Annals and Magazine of Natural History 10: 338353.

Bush, A. O., K. D. Lafferty, J. M. Lotz, and A. W. Shostak. 1997. Parasitology meets ecology on its own terms: Margolis et al revisited. Journal of Parasitology 83: 575583.

Chabaud, A. 1954. Sur le cycle évolutif de spirurides et de nématodes ayant une biologie comparable. Valeur systématique de caractères biologiques. Annales de Parasitologie Humaine et Comparée 29: 42-88. , 1978. Keys to genera of the superfamilies Coscocercoidea, Seuratoidea, Heterakoidea and Subuluriodea. In $\mathrm{CIH}$ keys to the nematode parasites of vertebrates: R. C. Anderson, A. G. Chabaud, and S. Willmott (eds). CAB International, Oxfordshire, U.K.: p. 50-51.

Dumbacher, J.P., G. B. Rathbun, T. O. Osborne, M. Griffin, and S. J. Eiseb, 2014. A new species of round-eared sengi (genus Macroscelides) from Namibia. Journal of Mammalogy 95: 443-454.

Fain, A. 1961. Pentastomides de l'Afrique Centrale. Annales du Musée Royale de 1'Afrique Centrale, Série 8, 92: 1-115.

Greve, J. H., and W. C. Russell, 1974. The brown hyaena (Hyaena brunnea), a new host for nymphal Armillifer armillatus (Pentastomida: Porocephalidae). Journal of Parasitology 60: 52.

Gedoelst, L. 1916. Notes sur la faune parasitaire $\mathrm{du}$ Congo Belge. Revue Zoologique Africaine 5: 1-90.

Hering-Hagenbeck, S. 2001. The metazoan parasite fauna of South African reptiles: With special attention to their nematodes. 
$\mathrm{PhD}$ thesis, Humboldt-University, Berlin, Germany, $325 \mathrm{p}$.

Hugot, J.-P., and D. Cuisance. 1990. Etude morphologique de Parasubulura gerardi Berghe and Vuylsteke, 1938 (Nematoda, Subuluroidea) parasite d'un Macroscelidae éthopien. Systematic Parasitology 16: 6776.

Lutermann, H., K. Medger, and K. Junker. 2014. Endoparasites of the spiny mouse (Acomys spinosissimus) from South Africa. Journal of Parasitology 100: 144-146.

Medger, K., C. T. Chimimba, and N. C. Bennett. 2012. Seasonal reproduction in the eastern rock elephant-shrew: influenced by rainfall and ambient temperature? Journal of Zoology 288: 283-293.

Ogden, C.G. 1968. Thelazia lewisi sp. nov. from a chequered elephant shrew in Uganda. Revue de Zoologie et Botanique Africaines 78: $1-4$.

Ogunsusi, R. A., and A. N. Mohammed. 1977. The chimpanzee (Pan troglodytes), a new host for nymphal Armillifer armillatus (Pentastomida: Porocephalida) in West Africa. Revue d'Elevage et de Médecine vétérinaire des Pays tropicaux 31: 361-362.

Ortlepp, R. J. 1937. South African helminths. Part 1. Onderstepoort Journal of Veterinary Science and Animal Industry 9: 311-337.

Petter, A. J. and J.-C. Quentin 1976. Keys to genera of the Oxyuroidea. In: CIH keys to the nematode parasites of vertebrates. R.C. Anderson, A. G. Chabaud, and S. Willmott (eds.). Oxfordshire, CAB International, U.K.: p. 236.

Quentin, J.-C. 1969. Cycle biologique de Protospirura muricola Gedoelst, 1916 Nematoda Spiruridae. Annales de Parasitolgie Humaine et Comparée 44: 485-504.

1970. Morphogénèse larvaire du Spiruride Mastophorus muris (Gmelin, 1790). Annales de Parasitolgie Humaine et Comparée 45: 839-855.

1978 .

Pterygodermatites

(Neopaucipectines) zaiedi n. sp., nouveau Nématode Rictulaire parasite du Macroscélide en Tunisie. Bulletin de Museé Histoire naturélle de Paris 351: 37-41. and C. Seureau. 1978. Identification et biologie du Gongylonème parasite du Macroscélide en Tunisie. Annales de Parasitolgie Humaine et Comparée 6: 631640.

, and J.-M. Verdier. 1979. Cycle biologique the Maupasina weissi Seurat, 1913 (Nématode Subuluroidea), parasite du Macroscélide. Ontogenèse des structures céphaliques. Annales de Parasitolgie 6: 621-635.

Rathbun, G. B. 2009. Why is there discordant diversity in sengi (Mammalia: Afrotheria: Macroscelidea) taxonomy and ecology? African Journal of Ecology 47: 1-13.

Redford, H., and J. G. Dorea. 1984. The nutritional value of invertebrates with emphasis on ants and termites as food for mammals. Journal of Zoology 203: 385395.

Riley, J., and J. T. Self, 1981. Some observations on the taxonomy and systematics of the pentastomid genus Armillifer (Sambon, 1922) in South East Asian and Australian snakes. Systematic Parasitology 2: 171179.

Sandground, J. H. 1933. Report on the scientific results of an expedition to the southwestern highlands of Tanganyika Territory. VI. Parasitic nematodes from East Africa and southern Rhodesia. Bulletin of the Museum of Comparative Zoology, Harvard College 75: 263-293.

Seurat, L.-G. 1913. Sur quelques Nématodes du Sud tunisien. Bulletin de la Société d'Histoire Naturelle de l'Afrique due Nord 6: $15-18$.

, 1914. Sur une Filaire Péritonéale du Macroscélide. Comptes Rendus Biologies 72: 523-527.

, 1915. Expédition de MM. Walter Rothschild, E. Hartert et C. Hilgert dans le Sud Algérien (Mars-Mai 1914). Nématodes parasites. Novitates Zoologicae 22: 1-25.

Skinner, J. D., and C. T. Chimimba. 2005. The mammals of the southern African subregion. Cambridge University Press, Cambridge, U.K. 812 p.

Speakman, J. R. 2008. The physiological costs of reproduction in small mammals. 
Philosophical Transactions of the Royal Society B 363: 375-398.

van den Berghe, L., and C. Vuylsteke. 1938. Les Parasubuluridae - Famille nouvelle d'Oxyuroidea au Congo Belge. Revue
Zoologie et Botanique Africaines 31: 376382.

Zumpt, F. 1961. The arthropod parasites of vertebrates in Africa south of the Sahara. Vol. I (Chelicerata). South African Institute of Medical Research, Johannesburg. 457 p. 
Figure 1. Variation in the abundance of (A) Maupasina weissi with season and (B) spiruroid larvae with season and sex in Elephantulus myurus from the Limpopo Province, South Africa.
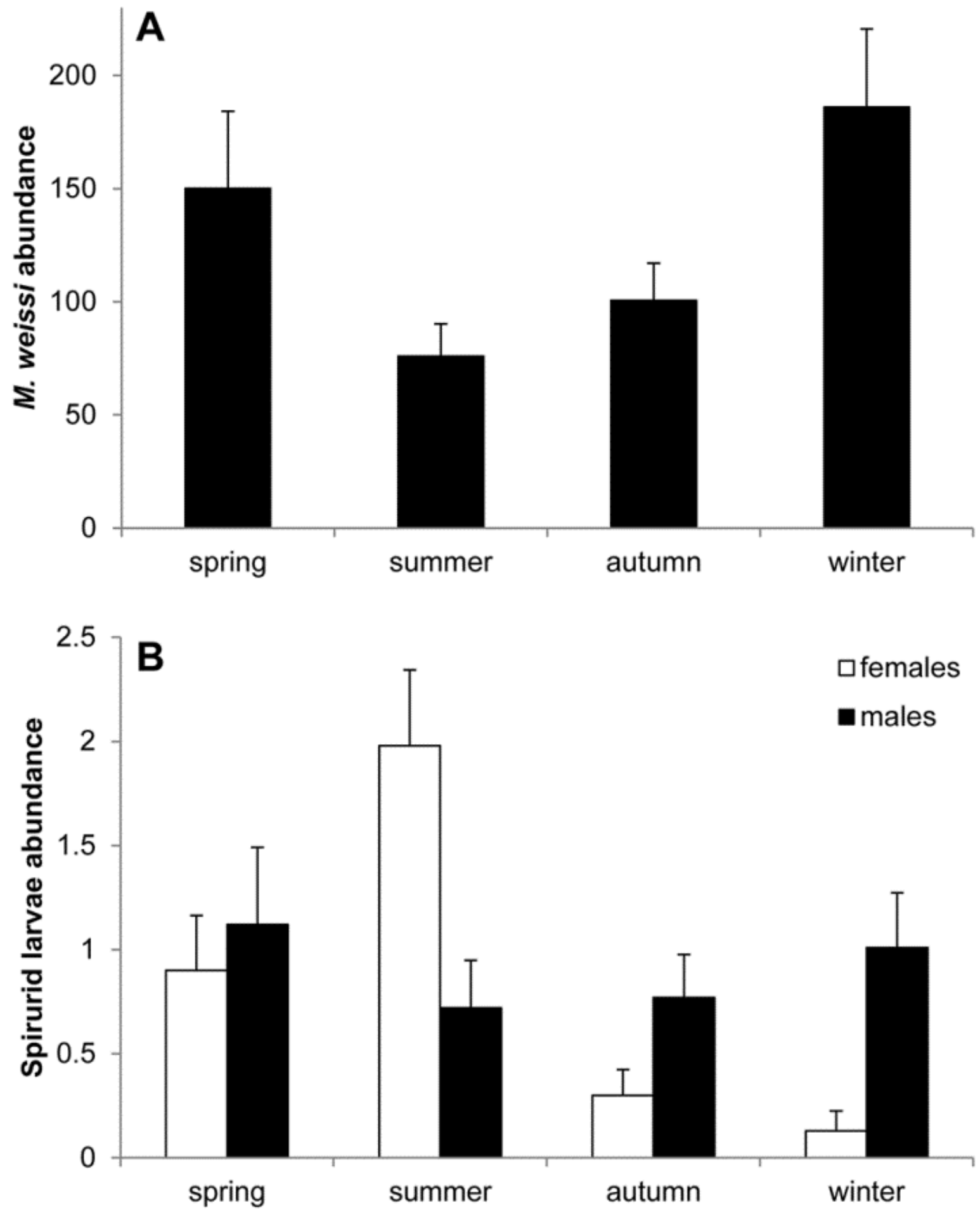
Table I. Endoparasites recovered from 121 Elephantulus myurus in the Limpopo Province, South Africa.

\begin{tabular}{|c|c|c|c|c|c|c|}
\hline Taxon & Life cycle & Site in host & Total count & Prevalence (\%) & Abundance (mean \pm SE) & Range \\
\hline \multicolumn{7}{|l|}{ Nematoda } \\
\hline Syphacia minuta & Direct & Cecum/colon & 23 & 1.7 & $0.19 \pm 1.84$ & $0-20$ \\
\hline Moaciria spp. & Direct & Cecum/colon & 4 & 0.8 & $0.03 \pm 0.36$ & $0-4$ \\
\hline Spinicauda spp. & Direct & Cecum/colon & 4 & 0.8 & $0.03 \pm 0.36$ & $0-4$ \\
\hline Maupasina weissi & Indirect & Cecum/colon & 15,367 & 99.2 & $127.00 \pm 84.87$ & $0-476$ \\
\hline Abbreviata spp. & Indirect & Stomach & 14 & 5.0 & $0.12 \pm 0.66$ & $0-5$ \\
\hline Physolapetra spp. & Indirect & Stomach & 26 & 7.4 & $0.21 \pm 1.08$ & $0-10$ \\
\hline Physalopterinae & Indirect & Stomach & 5 & 1.7 & $0.01 \pm 0.09$ & $0-1$ \\
\hline Spiruriod larvae & Indirect & Stomach & 111 & 24.0 & $0.92 \pm 0.207$ & $0-13$ \\
\hline Trichuris spp. & Direct & Cecum/colon & 5 & 1.7 & $0.04 \pm 0.33$ & $0-3$ \\
\hline \multicolumn{7}{|l|}{ Cestoda } \\
\hline Hymenolepididae* & Indirect & Small intestines & - & 4.1 & - & - \\
\hline \multicolumn{7}{|l|}{ Pentastomida } \\
\hline Armillifer armillatus & Indirect & Body cavity & 21 & 6.6 & $0.17 \pm 0.88$ & $0-8$ \\
\hline
\end{tabular}

*no scoleces were recovered and hence the number of cestodes could not be determined. 
Table II. List of endoparasites recorded from Macroscelidae prior to this study

\begin{tabular}{|c|c|c|c|}
\hline Taxon & Locality & Host species & Reference \\
\hline \multicolumn{4}{|l|}{ Nematoda } \\
\hline \multirow[t]{4}{*}{ Maupasina weissi } & Southern Tunesia $^{1}$ & Elephantulus rozeti ${ }^{2}$ & $\mathrm{a}$ \\
\hline & Zimbabwe & $\begin{array}{l}\text { Elephantulus } \\
\text { brachyrhynchus }\end{array}$ & $\mathrm{p}$ \\
\hline & Zaire & R. cirnei & $\mathrm{p}$ \\
\hline & South Africa & Elephantulus sp. & $\mathrm{i}$ \\
\hline \multirow[t]{2}{*}{ Parasubulura gerardi } & Zaire $^{1}$ & Petrodromus tetradactylus ${ }^{2}$ & $\mathrm{j}$ \\
\hline & Zimbabwe & $\begin{array}{l}\text { Elephantulus } \\
\text { brachyrhynchus }\end{array}$ & $\mathrm{p}$ \\
\hline $\begin{array}{l}\text { Parasubulura callosa (syn. } \\
\text { Subuluara callosa) }\end{array}$ & Zimbabwe $^{1}$ & Petrodromus tetradactylus ${ }^{2}$ & $g ; j$ \\
\hline $\begin{array}{l}\text { Parasubulura petrodromi (syn. } \\
\text { Numidica petrodromi) }\end{array}$ & Tanzania $^{1}$ & Petrodromus tetradactylus ${ }^{2}$ & $\mathrm{~h} ; \mathrm{j} ; \mathrm{p}$ \\
\hline $\begin{array}{l}\text { Pterygodermatites } \\
\text { (Neopaucipectines) zaiedi }\end{array}$ & Southern Tunesia $^{1}$ & Elephantulus rozeti ${ }^{2}$ & $\mathrm{n}$ \\
\hline Thelazia lewisi & Uganda $^{1}$ & $\begin{array}{l}\text { Rhynchocyon cirnei }{ }^{2} \text { (syn. } R \text {. } \\
\text { cirnei stuhlmanni) }\end{array}$ & 1 \\
\hline Gongylonema brevispiculum & Tunesia $^{1}$ & Elephantulus rozeti $^{2}$ & o \\
\hline Spirurida rothschildi & Algeria $^{1}$ & $\begin{array}{l}\text { Elephantulus rozeti }{ }^{2} \text { (syn. } \\
\text { Elephantulus deserti) }\end{array}$ & $\mathrm{c}$ \\
\hline $\begin{array}{l}\text { Cyathospirura chevreuxi (syn. } \\
\text { Habronema chevreuxi) }\end{array}$ & Tanzania $^{1}$ & $\begin{array}{l}\text { Petrodromus tetradactylus } \\
\text { (syn. Petrodromus nigriseta) }\end{array}$ & $\mathrm{a} ; \mathrm{h}$ \\
\hline $\begin{array}{l}\text { Acanthocheilonema weissi } \\
\text { (syn. Microfilaria matamatae }\end{array}$ & $\begin{array}{l}\text { North Africa }{ }^{1}, \\
\text { Tunisia }\end{array}$ & $\begin{array}{l}\text { Elephantulus rozeti }{ }^{2} \text { (syn. } \\
\text { Elephantulus rozeti deserti) }\end{array}$ & $\mathrm{b} ; \mathrm{m}$ \\
\hline $\begin{array}{l}\text { Onchocercella katangensis } \\
\text { (syn. Grammophora } \\
\text { katagensis) }\end{array}$ & $\mathrm{DRC}^{1}$ & Petrodromus tetradactylus & $\mathrm{d}$ \\
\hline \multicolumn{4}{|l|}{ Cestoda } \\
\hline $\begin{array}{l}\text { Hymenolepis s.1. } \\
\text { macroscelidarum }\end{array}$ & South Africa ${ }^{1}$ & $\begin{array}{l}\text { Elephantulus } \\
\text { brachyrhynchus }^{2} \text { (syn. } \\
\text { Macroscelides } \\
\text { brachyrhynchus) }\end{array}$ & e \\
\hline Hymenolepis s.1. petrodromi & Zimbabwe $^{1}$ & Petrodromus tetradactylus ${ }^{2}$ & $\mathrm{f}$ \\
\hline Hymenolepis sp. & Tanzania & $\begin{array}{l}\text { R. cirnei (syn. R. cirnei } \\
\text { hendersoni) }\end{array}$ & $\mathrm{f}^{*}$ \\
\hline \multicolumn{4}{|l|}{ Pentastomidae } \\
\hline Armillifer armillatus & unspecified & unidentified & $\mathrm{k}$ \\
\hline
\end{tabular}

${ }^{1}$ type locality; ${ }^{2}$ type host; ${ }^{a}$ Seurat (1913); ${ }^{b}$ Seurat (1914); ${ }^{\mathrm{c}}$ Seurat (1915); ${ }^{\mathrm{d}}$ Gedoelst (1916); ${ }^{\mathrm{e}}$ Baer (1926); ${ }^{\mathrm{f}}$ Baer (1933); ${ }^{\mathrm{g}}$ Sandground (1933); ${ }^{\mathrm{h}}$ Baylis (1934); ${ }^{\mathrm{i}}$ Ortlepp (1937); ${ }^{\mathrm{j}} \mathrm{van}$ den Berghe and Vuylsteke (1938); ${ }^{\mathrm{K} Z u m p t ~(1961) ;}{ }^{\mathrm{l} O g d e n}$ (1968); ${ }^{\mathrm{m}}$ Bain and Quentin (1977); ${ }^{\mathrm{n}}$ Quentin (1978); ${ }^{\circ}$ Quentin and Seureau (1978); ${ }^{\mathrm{p}}$ Hugot and Cuisance (1990); *no description provided, specimen in poor condition without scolex 